\title{
Same Table, Different Menus? A Comparison of $U N$ and EU Mediation Practice in the Kosovo-Serbia Conflict
}

\author{
Julian Bergmann
}

Deutsches Institut für Entwicklungspolitik/German Development Institute (DIE), Tulpenfeld 6, 55113 Bonn, Germany

julian.bergmann@die-gdi.de

Received 12 June 2017; accepted 22 October 2017

\begin{abstract}
This article compares UN and EU mediation practice in the Kosovo-Serbia conflict. It proposes a conceptual framework to analyze mediation effectiveness and its conditions and applies it to the UN-led Kosovo Status Talks in Vienna (2006-2007) and the ongoing EU-facilitated dialogue between Belgrade and Pristina (since 2011). The EU's relatively high degree of effectiveness compared to the UN effort can be partly explained by the application of a strategy of manipulation, drawing on the EU's strong leverage vis-à-vis both sides; partly by pointing to the conflict context which has been more favorable to mediation since 2011. At the same time, the analysis reveals that EU mediation has not led to any changes concerning Serbia's stance toward the

* Julian Bergmann is a post-doctoral researcher at the German Development Institute. His research interests revolve around EU foreign, security and development policy, with a particular focus on EU involvement in conflict prevention and mediation. Before joining the DIE, he worked as a lecturer and research fellow with the Chair of International Politics at the Department of Political Science of Johannes Gutenberg University Mainz. He received his PhD in March 2017, defending his thesis on "Bargaining for Peace, Striving for Stability: A Study on the European Union's Effectiveness as International Mediator." I would like to thank the anonymous referees and the Editor of this journal as well as Arne Niemann, Geoffrey Edwards and Solveig Richter for helpful and constructive comments on earlier drafts. Parts of the author's research related to this article were facilitated by a grant from the German Foundation for Peace Research whose support is gratefully acknowledged. In addition, I am grateful to all interview partners who shared their insights and views with me.
\end{abstract}

(C) JULIAN BERGMANN, 2018 | DOI 10.1163/15718069-23021156

This is an open access article distributed under the terms of the prevailing CC-BY-NC license at the time of publication. 
recognition of Kosovo's independence. The continuing non-resolution of the conflict demonstrates the limits of the EU's manipulative mediation approach and points to a substantial dilemma of EU mediation.

\section{Keywords}

mediation - EU mediation - European Union - United Nations - Kosovo Status Talks - Kosovo - Serbia

\section{Introduction}

The most frequent providers of international mediation are states, accounting for almost forty percent of all mediation attempts since 1945, followed closely by international organizations (IOs) (Bercovitch \& Fretter 2007: 164; Bercovitch \& Schneider 2000: 156). Among the latter, the United Nations is (still) the clear frontrunner when it comes to frequency of mediation engagements by international organizations (Greig \& Diehl 2012: 68). In contrast, the European Union's share of mediation activities is marginal, although the EU has systematically strengthened its capacities for mediation and dialogue in recent years and has become a more active provider of mediation, particularly in its Eastern neighborhood (Bergmann \& Niemann 2015: 957).

While there is an emerging body of literature on EU mediation (Bergmann et al. 2018) we know relatively little about the distinctiveness of the EU's approach to mediation and to what extent its emerging profile as international mediator makes a difference in terms of mediation effectiveness. In other words, there is a lack of comparative work that contrasts $\mathrm{EU}$ mediation practices with those of other international actors. Accordingly, the main goal of this article is to put EU mediation in comparative perspective and to investigate in what ways EU mediation behavior differs from and is tentatively more/ less effective than mediation by the UN. The article focuses on UN and EU mediation in the Kosovo-Serbia conflict and addresses the following research questions:

(1) How do the UN and EU differ in terms of mediation style and behavior in the case of the Kosovo-Serbia conflict?

(2) To what extent can we relate the varying degrees of effectiveness of UN/ EU mediation to the (potential) difference in mediation behavior? 
The Kosovo-Serbia conflict is a particularly interesting context to study un and EU mediation in comparative perspective because it has seen four different episodes of mediation initiated by the UN and/or Eu since the outbreak of the Kosovo war in 1998: the Rambouillet Conference initiated by the UN Contact Group on Former Yugoslavia (1999); the Kosovo Status Talks led by UN Special Envoy Martti Ahtisaari (2006-07) with the EU as observer; the Troika process led by the Us, Russia and the EU (2007), and the Belgrade-Pristina dialogue being mediated by the EU since 2011. Assuming that it is easier to isolate the effect of mediator behavior on mediation outcomes in single-mediator cases rather than in multi-party mediation, I compare the Kosovo status talks led by un Special Envoy Matti Ahtisaari with the EU-mediated Belgrade-Pristina dialogue. These cases seem to be an adequate choice for comparing the mediation practice of different actors because the constellation of conflict parties and conflict issues has remained relatively stable over time.

The remainder of this article is structured as follows: first, I introduce the conceptual framework to investigate mediation effectiveness, focusing on mediation strategy and conflict parties' willingness to compromise as main conditioning factors. Second, I apply this framework to the abovementioned cases and trace the influence of UN and EU mediation behavior on mediation effectiveness. Third, I discuss the empirical results across cases and, finally, reflect on the EU's distinctiveness as international mediator.

\section{Conceptual Framework}

Mediation success is a contested concept in mediation research and has been conceptualized in a number of different ways (Kleiboer 1996: 361-362). Process-related definitions focus on criteria such as fairness and efficiency, while outcome-oriented definitions may either refer to subjective criteria such as conflict parties' perceived fairness or objective indicators such as effectiveness in terms of results achieved and/or change brought about through the mediation effort (Bercovitch 2005:294). Adopting an outcome-oriented understanding, this article opts for mediation effectiveness as the main dependent variable. A mediation effort is evaluated as effective when it has led to agreements reached between the conflict parties. More specifically, I propose to differentiate between the following values of conflict settlement:

(a) Full settlement: mediation leads to agreement(s) that solve(s) all issues of incompatibility between the parties

(b) Major Settlement of conflict: The majority of conflict issues has been fully or partially settled through negotiated agreements 
(c) Minor settlement of conflict: A small number of conflict issues has been fully or partially settled through negotiated agreements

(d) Process agreement: no agreement on the settlement of conflict issues, but agreement to hold further rounds of negotiations, establishment of procedural aspects for talks or strategies for implementation of concessions

(e) No agreement/failure: mediation does not lead to any agreement between the parties (cf. Bercovitch \& Langley 1993: 674; Bergmann \& Niemann 2015: 961).

These values correspond to the following degrees of mediation effectiveness: (a) effectiveness is very high if there is a full settlement of the conflict; (b) effectiveness is high if there is a major settlement of the conflict; (c) effectiveness is medium if there is a minor settlement of the conflict; (d) effectiveness is low if there is only a process agreement; and (e) EU effectiveness is very low if there is no agreement at all. Additionally, the analysis of conflict settlement also takes into account the sustainability of agreements, i.e. whether reached agreements have been implemented.

Having operationalized mediation effectiveness, I now turn to the conceptualization of mediator behavior that is the main independent variable which the cross-case comparison of UN/EU mediation in the Kosovo-Serbia conflict focuses on. More specifically, the analysis revolves around mediation strategy which is understood by mediation scholars as referring to the overall degree of control the mediator exerts on the bargaining process (Bercovitch \& Houston 2000: 175). In this article, I adopt the widely used taxonomy of three ideal types of mediation strategies: (a) facilitation-communication, (b) formulation, and (c) manipulation (Beardsley et al. 2006: 62-64; Touval \& Zartman 1985: 12-13).

A mediator as facilitator focuses on supplying (missing) information about the conflict and each side's interests to the parties, arranges for interactions between them, and provides for a negotiation environment that both promotes trust and confidence in the mediator as well as enables the disputants to openly and constructively discuss their interests and needs. The mediator seeks to enable exchanges of communication between the parties through the trilateral negotiation structure. A mediator as formulator takes a more proactive role in structuring the agenda, controlling the procedures and timing of negotiations and making proposals and suggestions for how to settle the conflict. Consequently, formulation implies a higher degree of control on the negotiation process, but without aiming to change the parties' cost-benefit calculations. The latter is exactly what distinguishes manipulation from other mediation strategies. Adopting a manipulative mediation role implies that the mediator exerts considerable pressure on the parties, drawing on his/her 
leverage to move parties toward agreement. Leverage is here understood as all resources of persuasion - be it military, economic or diplomatic tools and instruments - that can be utilized either to offer incentives for compromise or to coercively spur an agreement between the disputants. In addition, the mediator as manipulator may also actively intervene into the negotiations by making substantive suggestions, taking responsibility for concessions and offering implementation assistance (Beardsley et al. 2006: 62-66; Capelos \& Smilovitz 2008: 75-76).

Empirical studies suggest that manipulation is the most effective mediation strategy to move disputing parties toward agreement (Gartner \& Bercovitch 2006: 833-34; Wallensteen \& Svensson 2014: 319-320). In line with these findings, I hypothesize that the more the mediator's behavior in the negotiations reflects elements of a manipulative strategy, the more effective the mediation effort.

Although mediation strategy is a main condition of mediation effectiveness, it is clear that conflict parties' negotiation behavior is equally important to explain mediation outcomes due to the trilateral character of mediation. For this reason, we also have to take into account conflict parties' willingness to compromise as an intermediary factor to understand the influence of mediation strategy on mediation effectiveness. It captures the conflict parties' motivation to settle their conflict and depends on their expectation of the benefits they would gain through a negotiated settlement (Bercovitch \& Lee 2003: 5). The assessment of the motivations, preferences and red lines of the conflict parties enables us to assess the zone of potential agreement between the parties and the degree of their willingness to compromise within this range (cf. Beardsley 2011: 19-43). If there is no overlap of conflict parties' preferences and, consequently, a zone of potential agreement does not exist, mediation strategy will not have an influence on the effectiveness of the mediation effort at all. At the same time, conflict parties' willingness to compromise is not fixed and may be subject to change. In this regard, mediation strategy and conflict parties' willingness to compromise are intertwined in the way that mediators may alter conflict parties' willingness to compromise through an expansion of the zone of agreement, for example by providing additional incentives to the parties or offering solutions for overcoming commitment problems (Beardsley 2011: 34-36).

1 However, studies also suggest that the application of manipulative strategies may have negative effects on the durability of agreements, given the risk to broker agreements based on artificial incentives that parties are not willing to implement when the mediator has withdrawn (Beardsley 2011: 114; Quinn et al. 2013: 209). 
Hence, the subsequent two case studies investigate the influence of mediation strategy on mediation effectiveness, also taking into account the potential explanatory power of conflict parties' willingness to compromise. They are based on a broader dataset of 50 interviews with officials from all relevant parties conducted between 2013-2016.

\section{The UN-led Kosovo Status Talks}

In November 2005, the Finnish diplomat and internationally experienced mediator Ahtisaari was appointed Special Envoy of the UN Secretary General of the United Nations for the Future Status Process for Kosovo. According to his mandate, Ahtisaari was tasked to lead a mediation process between Belgrade and Pristina which should result in a proposal for the settlement of Kosovo's status to be submitted to the UN Security Council through the SecretaryGeneral. Athisaari was given considerable room to maneuver by the members of the UN Contact Group on Kosovo ${ }^{2}$ and the UN Security Council, indicating right from the beginning that the mediation process could last throughout 2006 (Crisis Group 2006a: 1). The Guiding Principles issued by the Contact Group emphasized that the conflict over Kosovo's status had to be resolved through a 'negotiated, rather than imposed, solution' (Perritt 2011: 121).

Briefly after his appointment, Ahtisaari set up a mediation team referred to as United Nations Office of the Special Envoy for Kosovo (UNOSEK) which was based in Vienna. ${ }^{3}$ Negotiations between the delegations of Belgrade and Pristina commenced in February 2006. UNOSEK invited the delegations to Vienna for several days to discuss one specific issue area over the entire period. Active shuttle diplomacy accompanied the mediation process. The UNOSEK team conducted 26 expert missions to Belgrade and Pristina to understand the parties' positions on individual issues and to float ideas and proposals for compromise solutions (Weller 2008: 664-66).

In terms of effectiveness as conflict settlement, the mediation effort has to be evaluated as a failure because it did not lead to any formal agreement between the parties. While there was some moderate rapprochement of positions on issues such as decentralization (Ker-Lindsay 2009: 37, 39, 41), 'in most areas, there was no progress at all' (Perritt 2011: 159). When Ahtisaari presented his draft for a Comprehensive Settlement Plan on 2 February 2007, the Serbs promptly rejected the proposal. Due to Russia's opposition, the Ahtisaari plan

2 France, Germany, Italy, the Russian Federation, the UK and the United States.

3 For further information on UNOSEK's staff composition, see Perritt (2011: 116-18). 
was never taken to a vote in the UN Security Council, which meant that the negotiation process did not result in any written agreement between the disputants. Consequently, in terms of conflict settlement, the Un mediation effort from 2006 to early 2007 was ineffective. ${ }^{4}$

To what extent can we attribute mediation failure to the mediator and the adopted mediation strategy? To answer this question, we first have to analyze UNOSEK's mediation strategy and then trace its influence on the mediation outcome. Based on the empirical data, I argue that UnOSEK's mediation style is best described as manipulation due to three main characteristics.

First, the UNOSEK team had a strong role in structuring the talks. Ahtisaari, from the very start of the process, had concluded that the final outcome should be some sort of supervised independence of Kosovo, a fact that he has openly acknowledged himself at a later stage (Ker-Lindsay 2010: 57-58; Fridl 2009: 81). Nevertheless, he and his team decided to start the negotiations with practical issues such as decentralization, cultural heritage and economic matters in order to bypass the status issue at this initial stage and press ahead with designing an independent country that would then be endorsed by the Security Council, with or without Serbia's acceptance (Ker-Lindsay 2010: $58-60) .5$

Thus, in contrast to the proposal by un Special Envoy Eide to set the agenda, format, and procedures for the talks in agreement with the parties in order to make the process inclusive and transparent, these decisions were primarily taken by the mediator (Fridl 2009: 81; Weller 2008: 670-71).

Second, the UNOSEK team also played an active role concerning the substance of the negotiations. UNOSEK prepared resource and information papers for the negotiations and invited external experts to individual negotiation sessions. In addition, the parties were asked to prepare position papers to facilitate the negotiations on specific issues (Perritt 2011: 145). Certainly, the most important contribution to the status negotiations was the preparation of the Comprehensive Settlement Plan by Athisaari. He presented the first draft to the parties on 2 February 2007, immediately after Serbia's parliamentary elections. However, the draft represented primarily the mediator's assessment of the most viable solution to the status issue and was not designed as a first template for further substantial discussions between the parties that would result in a negotiated compromise solution (Fridl 2009: 73). Although Ahtisaari emphasized vis-à-vis the two parties that he would be willing to consider "constructive amendments," there was little belief on both sides that significant changes to the proposals were possible at this stage (Ker-Lindsay

4 For a similar assessment, see Fridl (2009).

5 I am grateful to one of the reviewers who pointed this out. 
2009: 6o). Thus, the UN mediators played the role of a formulator as regards to the discussion of technical issues, but it was not before the unveiling of the Comprehensive Settlement Plan that they put proposals on the status issue on the negotiation table.

Third, there is no indication that the mediation team drew on any kind of leverage to move the parties toward a compromise agreement, which would be a clear indication of a manipulative mediation strategy. While UNOSEK as an organ mandated by the Security Council was not able to draw on any kind of resources on its own, the members of the Contact Group also did not provide leverage to encourage both sides to reach an agreement that was acceptable to both (Ker-Lindsay 2009: 107). The Quint countries, and in particular the Us, were prepared to accept Serbia's long-term alienation in exchange for Kosovo's independence that was conceived as inevitable, which may explain why the Contact Group did not reach out to Serbia to move them toward a more positive attitude toward the negotiations (Perritt 2011: 130). As far as Russia was concerned, there was also no willingness to incentivize Serbia to play a more constructive role in the negotiations at this stage of negotiations. Rather, Vitaly Churkin, the Russian Permanent Representative to the Un, repeatedly stressed that the international community had no "legal, political or moral grounds to force Serbia into a solution" (Reuters 13 July 2006).

Despite the non-use of leverage, there was one manipulative element in the UN's mediation approach - that was to recommend a particular solution to the conflict and pressuring the parties to accept this proposal (Beardsley et al. 2006: 64). When investigating UNOSEK's mediation behavior, it becomes evident that this was indeed the main characteristic of their mediation approach. Even before the beginning of direct discussions, Ahtisaari had stressed in a meeting with Serbian President Tadic and Prime Minister Kostunica that his conviction was that the process would lead to some form of independence for Kosovo. As Ker-Lindsay concludes in his analysis of the Kosovo status talks,

once Ahtisaari took up his appointment, he made almost no attempt to hide the fact that he believed that independence was the only outcome of the process (...) In this sense, Ahtisaari was less a mediator than an arbitrator. He did not seek compromise between the parties on the question of status, believing that one was not possible, but instead sought to use the talks as a means of drawing up proposals for a multiethnic and independent Kosovo (Ker-Lindsay 2009: 110-11).

Even at later stages, the UN mediators as well as some members of the Contact Group tried to push the Serbian government toward accepting their 
responsibility for what happened during Milosevic's reign and acknowledging that it was not possible to expect Kosovo Albanians to live under Serbian rule ever again (Fridl 2009: 83-84; Ker-Lindsay 2009: 42). In addition, there was the hope on the side of the UN mediation team that Russia would in one way or another buy into this argument (interview A). Overall, Ahtisaari entered the negotiations with his mind made up 'and rather than trust-building or uniting the two parties into a compromise, solely concentrated all of his efforts on coercing Serbia toward a pre-determined outcome' (Fridl 2009: 81; see also Ker-Lindsay 2010, 2011).

However, the diplomatic pressure exerted by UNOSEK and the members of the Contact Group except from Russia actually led to a deterioration of the relations between Serbia and the Un (Ker-Lindsay 2009: 37-39, 51, 59). The empirical evidence suggests that this mediation strategy resulted in an enormous lack of trust in the mediator and his team on the side of the Serbian delegation. Ahtisaari, who had been one of the key figures in negotiating Serbia's withdrawal from Kosovo in 1999, was perceived as an adversary rather than an impartial mediator (Fridl 2009: 82).

The Serbian delegation's perception of Ahtisaari's partiality became even stronger when Ahtisaari communicated forthrightly to the Serbian government that the Quint countries desired Kosovo's independence to be the final outcome of the negotiations (Perritt 2011: 115). When Ahtisaari presented his Comprehensive Settlement Plan, it was perceived as a fait accompli imposed on Serbia (Economides 2011: 197).

While it seems justified to criticize Ahtisaari and his team for not having invested more time and resources in building trust between the parties, the question is whether a different mediation strategy had made a difference. The analysis of conflict parties' willingness to compromise clearly indicates that the space for compromise and potential agreement between the disputants was virtually zero. As one participant to the Kosovo Status Talks remembers, the Serbian delegation's perception was that

the Vienna negotiations were 'stage negotiations' (...) from day one, it was very clear that the positions of the two sides were so far away that there was no possibility of these things to be closed. The gap was so big, because it was independence versus no independence (interview B).

From the Serbian point of view, the Vienna talks thus only served as a means to prepare the ground for Ahtisaari to provide his proposal for a solution that would favor Kosovo's independence. Nevertheless, it has to be acknowledged that Ahtisaari's approach of pre-determining the outcome of the negotiations 
contributed to Serbian resentment toward his partiality and "served to inflame Serbian tensions needlessly" (Ker-Lindsay 2010: 6o). In fact, the Serbian side was divided between President Tadic who was strongly committed to Serbia's integration into the West and Prime Minister Kostunica, a nationalist who was very critical of the United States and the European Union. The way of how the mediator conducted the Kosovo Status Talks thus provided another argument for Serbian nationalists to question the legitimacy of the negotiations and claim that Serbia was treated in an unjust and unfair way by the international community.

In reaction to Ahtisaari's mediation approach, the Serbian delegation then sought to undermine the legitimacy of the status process and make it as difficult as possible for Ahtisaari and his team (interview B; Perritt 2011: 127).

In sum, UN mediation in the case of the Kosovo status negotiations was characterized by an active mediator who had adopted a strategy of manipulation to pressure Serbia into a pre-determined outcome: the independence of Kosovo. Ahtisaari had drawn the conclusion very early in the negotiations that a negotiated settlement between the parties was very unlikely due to their incompatible positions and thus sought to pressure Serbia into accepting Kosovo's independence. The mediation strategy was doomed to fail because without the use of leverage, there were no incentives for both parties to change their positions, particularly not for the Serbian delegation. The Serbian unwillingness to accept Ahtisaari's Comprehensive Settlement Plan was reinforced by the perception of Ahtisaari's partiality toward Pristina. Although conflict parties' low willingness to compromise is the main variable that explains the failure of the mediation process, the evidence suggests that mediation strategy and UNOSEK's partiality toward Kosovo Albanians contributed to this failure.

\section{Eu Mediation in the Belgrade-Pristina Dialogue}

In July 2010, the International Court of Justice (ICJ) issued an advisory opinion on request of the UN General Assembly concerning Kosovo's unilateral declaration of independence (UDI) in 2008. The ICJ concluded that Kosovo's UDI "did not violate any applicable rule of international law" (International Court of Justice 2010: 53). Following the ICJ's advisory opinion, Belgrade announced that it would seek to gather support for a UN General Assembly resolution calling for renewed status talks. Put under pressure by the Eu not to take any further steps aimed at undermining the effect of the ICJ advisory opinion, the Serbian government finally agreed to an EU proposal for a joint UN General Assembly Resolution calling for a dialogue between Belgrade and Pristina under the 
facilitation of the EU (Tannam 2013: 955-56). According to Resolution 64/298 that was adopted on September 8, 2010, this dialogue 'would be to promote cooperation, achieve progress on the path to the European Union and improve the lives of the people' (United Nations General Assembly 2010: 2).

In March 2011, the first round of talks between delegations from Belgrade and Pristina facilitated by Robert Cooper, High Representative Ashton's advisor on the Western Balkans, was held in Brussels. After one year of monthly negotiations and an eight-month break between February and October 2012, the parties agreed to resume the mediation process as high-level political dialogue between their prime ministers, chaired by the High Representative Catherine Ashton (Bergmann \& Niemann 2015: 965).

In this format, the EU has managed to broker seven agreements on so-called technical issues, such as the recognition of university diplomas, return of cadasters and civil registry books, the management of the boundary/border and Kosovo's recognition in regional fora such as CEFTA (Malazogu \& Bieber 2012; New Policy Center 2013). In the high-level political dialogue, arrangements were reached for energy and telecommunications, and most importantly, the political representation of Kosovo Serbs in Northern Kosovo and the integration of Northern Kosovo's justice and security structures into Kosovo's legal framework.

Although the Belgrade-Pristina dialogue is still ongoing, we can nevertheless ascertain that the degree of mediation effectiveness in terms of conflict settlement is higher than in the case of the status talks led by Ahtisaari. In the period between March 2011 and August 2015, the mediation effort led to sixteen agreements on issues of incompatibility between the parties. ${ }^{6}$ Most importantly, the April 2013 First Agreement of Principles Governing the Normalization of Relations provides a solution to the conflict over the governance of Northern Kosovo, although some elements of the agreements, such as the envisaged creation of an Association/Community of Serb majority municipalities in Kosovo, have not yet been fully implemented. Despite these achievements, Kosovo's status remains the most contested issue between the two parties. In addition, a number of conflict issues - such as Kosovo's (potential) membership in the UN and other multilateral international organizations, property rights, preservation of religious and cultural heritage and the issue of missing persons - have not been settled or even addressed yet (Deda \& Qosaj-Mustafa 2013; interviews C, D). Focusing on the extent to which conflict issues have been formally settled

6 For a detailed discussion of the different agreements, see Bergmann (2017); Deda \& QosajMustafa (2013); Crisis Group (2013); and Malazogu \& Bieber (2012). 
by agreements, the EU mediation effort thus represents a major settlement of the conflict, with a majority of issues fully or partially settled. However, taking into account the lagging implementation of many agreements, which demonstrates the incompleteness and fragility of the process, leads to a less positive assessment (cf. Bergmann \& Niemann 2017: 7; Bieber 2015: 311). In particular, the April 2013 Agreement represents 'a plan of management of the relations between Pristina and Belgrade, rather than a clear roadmap with a series of milestones and objectives' (SEESOX 2014: 4-5). Taking both aspects together, mediation effectiveness in this case is thus evaluated as being medium, reflecting both the achievements and the unresolved status of a number of conflict issues, including the question of Kosovo's final status.

Based on the empirical analysis, I argue here that the EU's mediation strategy largely explains the medium degree of mediation effectiveness. In contrast to the UN approach, the EU adopted a process-oriented rather than outcomeoriented approach to the mediation process (Visoka \& Doyle 2016). Based on the parties' consent, it opted for starting the negotiations by discussing technical issues first, such as customs, return of civil registry books and cadasters (Cooper 2015: 1; Perritt 2011: 156). At the same time, the parties agreed that the talks should be status-neutral (interview E). In contrast to the UN mediation effort, the EU mediators could hold up to this principle because they were not given the explicit mandate to resolve the status issue. In contrast to the UN effort in 2006/7, however, the EU has played a stronger formulator role in the negotiations. The EU structured the talks by chairing and hosting the negotiations, presenting a list of possible topics to discuss and proposing potential compromise solutions on individual issues (Bergmann \& Niemann 2015: 967-68). In the discussions about integrated border management (гвм), for example, the EU mediation team invited a European Commission expert to give a presentation about how Hungary and Austria had implemented IBM before Hungary joined the EU in 2004. As one interview partner stated,

every time we had some impasse or moments where we could not move further to achieve something, we looked at what are the Eu's standards and solutions for the particular issue and that enabled us in the end to find a solution (interview F).

When the parties discussed the re-start of negotiations in October 2012 after an eighth-month break, HR Ashton presented a list of possible topics for discussion to provide some fresh impetus for the talks (interview $G$ ). As one participant to the mediation process noted, in some instances, the EU acted 
as "an active mediator and initiator of concrete agreements reached within the dialogue process, seeking compromises and also proposed solutions" (interview G).

In stark contrast to the UN mediation case, the EU's mediation strategy also includes elements of manipulation in the form of positive incentives for agreement. Due to conflict parties' strong aspirations for EU membership, the EU possesses a high degree of leverage vis-à-vis the conflict parties: "enlargement is the big pull factor, the main carrot the EU has to offer" (interview C). According to the interview evidence, the EU has actively and purposefully drawn on this leverage to spur agreement between the parties (interviews D, H, I). As one interview partner explained,

it is not the case that we were put directly under pressure by the EU, but let's say the EU became more active on certain occasions, especially prior to June and December Council meetings. It was communicated to us that we have to deliver something for these Council meetings in order to move forward on the path toward European integration (interview I).

Additional conditionality toward Serbia was applied by individual EU member states. As Economides and Ker-Lindsay (2015: 1036) point out, it was particularly Germany that threatened to block Serbia's accession if there was no progress in the dialogue negotiations and the implementation of agreements. These tactics are distinct features of a manipulative mediation style.

At the same time, the Eu's mediation strategy could only be effective because the conflict parties' willingness to compromise provided a fertile ground for negotiated agreements. In other words, it has to be acknowledged that another major conducive factor was both parties' shared interest in improving the status quo situation in Northern Kosovo and moving forward on their path toward EU accession (Bieber 2015: 312). On the side of the Kosovo government, the main goals were to put the Northern part under its formal control and to ensure the North's integration into Kosovo's legal and political framework, as well as accelerating the EU integration process and thereby gaining the recognition of EU member states that have not recognized Kosovo yet (interview I). On the Serbian side, the government was willing to make concessions in the dialogue process primarily because of economic motives, given that the EU is seen in Serbia as a key driver of national economic growth (Economides \& Ker-Lindsay 2015: 1037). In addition, Serb government officials seemed to have realized that normalizing the relations with Pristina is the key to moving forward toward EU membership (interviews K, L; Economides \& Ker-Lindsay 2015: 1036-39). 
However, conflict parties' willingness to compromise has its limits. All compromises have fallen in the zone of agreement that is delineated by conflict parties' red lines - Serbia's firm rejection of Kosovo's independence and Kosovo's insistence on its independence and territorial integrity as well as the principle that every agreement must be in line with Kosovo's constitution and Ahtisaari's Comprehensive Settlement Plan (Kosovo Assembly 2011: 1; interviews F, I, J). While Serbia has modified its approach toward the governance of Northern Kosovo, non-recognition remains a firm red line for Belgrade in the talks with Pristina. According to some observers, the opposition against recognition has even hardened (Crisis Group 2013: 10; Economides \& Ker-Lindsay 2015: 1038).

In sum, the EU mediation effort in the Kosovo-Serbia conflict led to remarkable, partial successes in its first three years. Although the Eu has not managed to broker a comprehensive agreement on all conflict issues, the mediation effort produced a series of agreements between the two sides which were unlikely to be achieved just a few years ago. The empirical evidence suggests that the EU's mixed strategy of formulation and manipulation has been a key factor in pushing the parties toward agreements, thereby exploiting conflict parties' willingness to compromise based on their expected gains of future EU accession. At the same time, the lagging implementation of agreements has resulted in a stagnation of the mediation process in the past three to four years that risks endangering the initial successes of the dialogue (Big Deal 2016).

\section{Cross-case Comparison of UN and EU Mediation in the Kosovo- Serbia Conflict}

The empirical analysis has revealed that both mediation teams applied tactics of formulation such as structuring the mediation process and putting different proposals for compromise solutions on the negotiation table. Despite this similarity, there are three main differences between UN and EU mediation in the Kosovo-Serbia conflict. First, while UN mediator Ahtisaari opted for an outcome-oriented approach and sought to pressure Serbia into a pre-determined outcome, the EU's mediation strategy was much more process-oriented, without pre-determining to what ends the Belgrade-Pristina dialogue should ultimately lead to (Bieber 2015: 315-316). In fact, EU institutions have stated that the main objective of the dialogue is the 'normalization of relations' between Kosovo and Serbia (Council of the EU 2012: 11), but have left it open whether this ultimately implies Serbia's recognition of Kosovo's independence (cf. Bergmann \& Niemann 2015: 965-966). Second, the Eu's process-orientation 
and the more inclusive mediation style compared to the UN's approach enabled the EU to establish itself as an impartial 'honest broker' between the two sides. Paradoxically, the EU's internal division between 23 Member States recognizing Kosovo and five "non-recognizers" lent further credibility to the EU's impartiality concerning the status question as the most important conflict issue between Kosovo and Serbia (Bergmann 2017). In contrast, UN mediator Ahtisaari's stance on the status issue significantly reduced the level of trust Serbian negotiators had in him as an impartial and legitimate mediator (Ker-Lindsay 2010: 58).

Third, the EU has been able to incentivize the parties toward compromise agreement, while the UN mediation team was not able to draw on any kind of leverage. Instead, the Ahtisaari team was reliant on external actors such as the Contact Group members to put additional pressure on the parties and/ or provide additional incentives for compromise. However, neither the Western states nor Russia were willing to support the mediation team in terms of leverage, but rather played the role of advocates of one of the two sides (Perritt 2011: 130).

Regarding the relationship between mediation strategy and mediation effectiveness, the empirical evidence thus seems to confirm the hypothesis that a manipulative mediation strategy based on the use of leverage leads to a higher degree of mediation effectiveness, particularly if it is combined with a process-oriented approach to the negotiations. Taking together the findings of the two case studies, one conclusion we can draw is that the EU's mediation strategy based on the strong use of leverage is a decisive factor that explains why the $\mathrm{EU}$ was more successful than the $\mathrm{UN}$ in brokering agreements between the parties. In conflict situations where the parties' positions are almost mutually exclusive, extensive use of leverage - while not pre-determining the final outcome of the mediation process - might be the only possible way to spur agreements even on rather technical and low-key issues.

At the same time, the empirical results also point to the significance of conflict parties' willingness to compromise to understand the different degrees of mediation effectiveness in the two cases. First, as Bieber (2015: 312) notes with regard to the Belgrade-Pristina dialogue, the EU's contribution alone "does not suffice to explain the success of the dialogue." Rather, the Eu utilized a window of opportunity that emerged in 2011 due to both parties' increasing willingness to discuss their conflict in a trilateral format with the strong expectation of being rewarded by the European Union. In particular, Serbia's willingness to engage more constructively in the EU-mediated negotiations with Pristina compared to its approach to the UN-led Kosovo Status Talks is primarily a function of the expected political and economic gains of $\mathrm{EU}$ accession in return 
for making concessions to normalize relations with Pristina (Economides \& Ker-Lindsay 2015: 1036-1039).

Second, the comparison of the two mediation cases also demonstrates that the zone of potential agreement between the parties remains to be relatively small, despite the EU's ability to use the EU membership prospective as an incentive to the parties. On each side, there has been little willingness to depart from their red lines and maximalist positions. The Kosovo government has insisted on Serbia's recognition of Kosovo's independence and the full integration of North Kosovo into the country's political and legal framework. The Serbian government, in turn, has been unwilling to recognize Kosovo's independence and has thus refused to accept any agreement that would implicitly or explicitly imply a de facto recognition of Kosovo's independence. This firm position has even hardened in the period after the conclusion of the Brussels Agreement in April 2013 (cf. Economides \& Ker-Lindsay 2015: 1038). In other words, the EU's mediation strategy based on the use of leverage has been decisive to broker agreements between the parties on a range of issues that were impossible to achieve in the 2006/7 Kosovo Status Talks, but it has not led to a major transformation of the conflict between Kosovo and Serbia. Concerning the influence of mediation strategy on mediation effectiveness, we observe that the high degree of control on the mediation process exerted by the $\mathrm{EU}$ had a positive effective in terms of conflict settlement, but it has not been sufficient to broker a compromise agreement on the international status of Kosovo that would finally settle the conflict.

\section{Conclusions}

What can we learn from the comparison of UN and EU mediation in the Serbia-Kosovo conflict, in particular with regard to the EU's distinctiveness as international mediator? Certainly, one comparative case study cannot ultimately answer this question. Nevertheless, there are some observations that could be useful for further studies addressing similar questions. Obviously, one main strength of the $\mathrm{EU}$ as a mediator in its neighborhood is its ability to use contractual relations with the countries in conflict as a channel to incentivize them to achieve progress in mediation processes. This leverage is even stronger if there is a clear EU membership perspective, as it is the case in the Western Balkans. In contrast, the UN largely relies on external actors such as the US or Russia in the case of Kosovo and Serbia to provide any kind of leverage to parties in conflict in order to encourage them to find a settlement to their conflict. 
However, the EU's strength in terms of leverage does not guarantee the EU's success in mediating a political settlement between conflict parties. The Kosovo-Serbia case indeed demonstrates the limits of a manipulative strategy and its dependence on conflict parties' willingness to compromise. Additionally, applying a manipulative strategy also comes with a risk that is potentially higher for the EU than for the UN. As Beardsley (2011) and Quinn et al. (2013) have pointed out, the strong use of leverage may in the short run increase the likelihood of conflict settlement, but also risks to produce agreements that are based on artificial incentives and have a higher likelihood of not being implemented and leading to renewed conflict. In other words, manipulation can "backfire" in the sense that it leads to domestic resistance against agreements that the parties would have not signed when there were no strong external incentives provided. While this is not to say that EU membership for Kosovo and Serbia is an artificial incentive, there is nevertheless the risk that the countries' further association to the EU may stall due to EU-internal divisions among the Member States, which could also mean a severe setback for the mediation process (Bergmann \& Niemann 2015: 970). Consequently, it remains to be seen if the EU's mediation strategy also pays off in the longterm, contributing to a full normalization between Kosovo and Serbia and thus further stabilizing a region that has been regularly shaken by violence for quite some time. The current deadlock in the Belgrade-Pristina dialogue as well as the stalled implementation of a number of agreements demonstrates the validity of this concern (Balkan Insight 2017).

\section{Interviews}

A Interview with retired EU official, Brussels, April 2016

B Interview with retired Serbian government official, Belgrade, September 2015

C Interview with European Commission official, Brussels, October 2013

D Interview with European Commission official, Brussels, November 2013

E Interview with retired EU official, October 2013

F Interview with Kosovo government official, Pristina, June 2015

G Interview with Serbian government official, Brussels, November 2013

$\mathrm{H}$ Interview with European External Action Service official, Brussels, October 2013

I Interview with Kosovo government official, Brussels, November 2013

J Interview with Kosovo government official, Pristina, May 2015 
K Interview with EU member state official, Belgrade, September 2015

L Interview with Serbian government official, Belgrade, September 2015

\section{References}

Balkan Insight (2017). "Kosovo-Serbia Talks Fail to Defuse Tensions." Balkan Investigative Reporting Network, February 2.

Beardsley, K. (2011). The Mediation Dilemma. Ithaca: Cornell University Press.

Beardsley, K.C., D.M. Quinn, B. Biswas, and J. Wilkenfeld (2006). "Mediation Style and Crisis Outcomes." Journal of Conflict Resolution 50, 1: 58-86.

Bercovitch, J. (2005). "Mediation Success or Failure: A Search for the Elusive Criteria." Cardozo Journal of Conflict Resolution 7: 289-302.

Bercovitch, J. and J. Fretter (2007). "Studying International Mediation: Developing Data Sets on Mediation, Looking for Patterns, and Searching for Answers." International Negotiation 12, 2: 145-173.

Bercovitch, J. and A. Houston (2000). "Why Do They Do It Like This? An Analysis of the Factors Influencing Mediation Behavior in International Conflicts." Journal of Conflict Resolution 44, 2: 170-202.

Bercovitch, J. and J. Langley (1993). "The Nature of the Dispute and the Effectiveness of International Mediation." Journal of Conflict Resolution 37, 4: 670-691.

Bercovitch, J. and G. Schneider (2000). "Who Mediates? The Political Economy of Conflict Management." Journal of Peace Research 37, 2: 145-65.

Bergmann, J. (2017). Bargaining for Peace, Striving for Stability. A Study on the European Union's Effectiveness as International Mediator. PhD Thesis, Johannes Gutenberg University, Mainz, January 2017.

Bergmann, J. and A. Niemann (2015). "Mediating International Conflicts: The European Union as an Effective Peacemaker?" JCMS: Journal of Common Market Studies 53(5): 957-975.

Bergmann, J. and A. Niemann (2017). "From Neo-functional Peace to a Logic of Spillover in EU External Policy: A Response to Visoka and Doyle." JCMS:Journal of Common Market Studies, online first.

Bergmann, J., T. Haastrup, A. Niemann and R. Whitman (2018). "Introduction: The EU as International Mediator - Theoretical and Empirical Perspectives." International Negotiation 22, 2: 157-176, this issue.

Bieber, F. (2015). "The Serbia-Kosovo Agreements: An EU Success Story?" Review of Central and East European Law 40, 3-4: 285-319.

Big Deal (2016). "Split Asunder: Four and a half year since negotiations began between BelgradeandPrishtina, thetworemainfarapart, and theriftin Kosovooverthedialogue 
is widening." Report 3, December 2015, Balkan Investigative Reporting Network, Internews Kosova and Centre for Research Transparency and Accountability.

Capelos, T. and J. Smilovitz (2008). "As a Matter of Feeling: Emotions and the Choice of Mediator Tactics in International Mediation." The Hague Journal of Diplomacy 3 , 1: $63-85$.

Cooper, R. (2015). "The Philosophy of the Belgrade-Pristina Dialogue." July 16, European Western Balkans, available at https://europeanwesternbalkans.com/2015/07/16/sirrobert-cooper-the-philosophy-of-the-belgrade-pristina-dialogue/, accessed April 20, 2016.

Council of the European Union (2009). "Concept on Strengthening EU Mediation and Dialogue Capacities." November 10, Brussels: Council of the European Union, available at http://eeas.europa.eu/cfsp/conflict_prevention/docs/concept_strengthening_eu_med_en.pdf, accessed June 24, 2014.

Council of the European Union (2012). "Council Conclusions on Enlargement and Stabilisation and Association Process." December 11, Brussels: 3210th General Affairs Council Meeting.

Crisis Group (2013). "Serbia and Kosovo: The Path to Normalisation." Europe Report 223, February 19, International Crisis Group, available at http://www.crisisgroup .org/en/regions/europe/balkans/kosovo/223-serbia-and-kosovo-the-path-to-nor malisation.aspx, accessed May 2, 2016.

Deda, I. and A. Qosaj-Mustafa (2013). "The Implementation of Agreements of KosovoSerbia Political Dialogue." Pristina: Kosovar Institute for Policy Research and Development.

Economides, S. (2011). "The making of a failed state: the case of Kosovo." European View 10, 2: $195^{-200 .}$

Economides, S. and J. Ker-Lindsay (2015). “Pre-Accession Europeanization': The Case of Serbia and Kosovo." JCMS:Journal of Common Market Studies 53, 5: 1027-44.

European Union (2015). 'European Union Common Position, Chapter 35: Other Issues, Item 1: Normalisation of Relations between Serbia and Kosovo," AD 12/15, November 30, Brussels.

Fridl, D. (2009). "Kosovo Negotiations: Re-visiting the Role of Mediation." International Negotiation 14, 1: 71-93.

Greig, J.M. and P.F. Diehl (2012). International Mediation. Cambridge: Polity Press.

Ker-Lindsay, J. (2009). Kosovo: The Path to Contested Statehood in the Balkans. New York: I.B. Tauris.

Ker-Lindsay, J. (2010). "The Importance of Process in Peacemaking." Peace Review: A Journal of Social Justice 22, 1: 57-64.

Ker-Lindsay, J. (2011). "Principles and the Partition of Kosovo." Peace Review: A Journal of Social Justice 23, 2: 228-234. 
Kleiboer, M. (1996). “Understanding Success and Failure of International Mediation.” The Journal of Conflict Resolution 40, 2: 360-89.

Malazogu, L. and F. Bieber (2012). "The Future of Interaction between Pristina and Belgrade." Series: Confidence Building Measures in Kosovo 3, September, Project on Ethnic Relations Kosovo.

New Policy Center (2013). “(Is There) A Way Forward for Serbia and Kosovo." Belgrade: New Policy Center.

Perritt, H.H. (2011). Road to Independence for Kosovo: A Chronicle of the Ahtisaari Plan. Cambridge: Cambridge University Press.

Prelec, M. (2013). “The Kosovo-Serbia Agreement. Why Less is More.” Across Eurasia, May 7 , International Crisis Group.

Quinn, D., J. Wilkenfeld, P. Eralp, V. Asal, and T. Mclauchlin (2013). "Crisis managers but not conflict resolvers: Mediating ethnic intrastate conflict in Africa." Conflict Management and Peace Science 30, 4: 387-406.

SEesox (2014). "Serbia/Kosovo: The Brussels Agreement and Beyond." South East European Studies at Oxford, Workshop Report.

Tannam, E. (2013). “The EU's Response to the International Court of Justice's Judgment on Kosovo's Declaration of Independence." Europe-Asia Studies 65, 5: 946-64.

Touval, S. and I.W. Zartman (1985). "Introduction: Mediation in theory," in S. Touval and I.W. Zartman, editors, International Mediation in Theory and Practice. Boulder: Westview Press, pp. 7-17.

United Nations General Assembly (2010). "Resolution adopted by the General Assembly $64 / 298$. Request for an advisory opinion of the International Court of Justice on whether the unilateral declaration of independence of Kosovo is in accordance with international law." Press Release A/Res/64/298, October 13, New York: United Nations General Assembly.

Visoka, G. and M. Doyl (2016). "Neo-Functional Peace: The European Union Way of Resolving Conflicts." Journal of Common Market Studies 54, 4: 862-877.

Wallensteen, P. and I. Svensson (2014). "Talking peace: International mediation in armed conflicts." Journal of Peace Research 51, 2: 315-27.

Weller, M. (2008). "The Vienna negotiations on the final status for Kosovo." International Affairs 84, 4: 659-81. 